\title{
Scanning Electron Microscopic Observations of the Luminal Surface of the Rat Uterus in the Process of Implantation and Its Hormonal Regulation
}

\author{
Kaname HAYASHI, Shozo HAMANISHI, Wenyuan LEE and Shimpei TOJO \\ Department of Obstetrics \& Gynecology Kobe University School of Medicine, \\ Kobe, Ikutaku (650), Hyogo, Japan (Director : Professor Shimpei Tojo)
}

In order to study the real ultrastructural changes and the hormonal regulation in the process of the implantation, scanning electron microscopic observations were made on the endometrial surface of delayed implantation and castrated rats.

1) In delayed implantation, many large cellular protrusions, dense arrangement of microvilli and several microapocrine-like structures were observed.

2) Around eight hours after the injection of estradial, which dose was enough to induce the implantation, features such as a lot of macroapocrine-like and microapocrinelike structures, bulging of the cellular surface suggested the increase of secretion.

Subsequently, the decrease of the secretion activity was implied from such features as wrinkling of the cellular protrusions, shortening or bending of the microvilli, and flattening of the cellular surfaces.

3) In the castrated rats, the microvilli were short and sparsely distributed.

Under the administration of progesterone in these rats, microvilli were arranged densely and a large cellular protrusion was distributed on every cell.

In contrast, at twelve hours after the administration of estradiol in these rats, many microapocrine-like structures were observed.

Moreover, under the sequential administration of progesterone and estradiol, these findings well resembled those with estradiol injection in delayed implantation.

4) The significance and relation of those ultrastructural changes with the ovumimplantation were dicussed.

(See pp. 813 827) 


\title{
着床過程に関与する内膜上皮表面の \\ 超微細構造の変化とその内分泌調節
}

\author{
神戸大学医学部産科婦人科学教室（主任 : 東條伸平教授） \\ 林 要, 浜西 正三, 李 文遠
}

（昭和49年 1 月26受付）

胚着床に関与する子宮内膜上皮表面の微細構造の変化とてのさいの性ステロイドの演ずる役割を究明 する目的で, ラット内膜について走查型電顕を用い観察した結果, 遅延着床時の内膜では巨大な細胞質 突起と比較的繁茂する微䋐毛が認められ，着床量の estradiol 投与後は分泌現象の元進を示唆する apocrine 樣突起の著明な形成をみ，ついでおそらくは分泌物の放出に原因すると思われる上皮の菲薄 化が認められた。 また著者らの実験条件下では protrusion の形成は主として progesterone 依存性, apocine 様突起の形成は主として estrogen 依存性であることも判明した。

\section{は じめに}

複雑な胚着床過程を解析する一つの方法論として遅姃着床実験がある。本条件下では肧の viability は維 持されるものの, 内膜への trophoblastic invasion はわこらないので, 妊卵保持あるいは肧着床阻止に関 与する progesterone の作用のメカニズムを研究する上に有用な実験モデルとなる.

ところで，乙のさい適量の estrogen を投与すれば，着床は直ちに誘起される：すなわち，乙の間の消息 を経時的に追求するてとは estrogen の肧着床促進作用のメカニズムを分析する上に有用である.

さて胚着床にさいして妊卵と最初に接触する場は附記するまでもなく，内膜表面上皮であるが，内膜表面 上皮は肧性刺激を内膜間質に伝達する transducer として機能するてとも明らかにされている (Blandau, 1961) ${ }^{1)}$.

したがつて, 肧着床と前後して生ずる内膜の超微細表面像の変化を追究するととは, 胚着床の機序の害態 を解明する上に極めて重要な課題と考えられる.

ところで従来着床周辺期にみられる内膜表面上皮の微細構造の変化につき検討した研究として, Enders ら $(1967)^{2)}$, Mayer ら $(1967)^{3)}$ をはじめ, Potts $(1969)^{4)}$, Nilsson $(1970)^{5)}$, Tachi ら $(1970)^{6}$, 飯塚 $(1971)^{7)}$, 著者ら $\left.\left(1972^{8}\right) ， 1973^{9}\right)$ の報告がみられるが，乙れらの報告はいずれも透過型電顕を用いた成績で，乙の さいの内膜表面上皮に生ずる微練構造の変化を広範囲, かつ立体的に追究するてとは, その方法論上, おの ずと一定の制約か残されていた。

そこで著者らは, 本研究において, 走査型電顕を用い, 遅延着床内膜の上皮表面, さらに estrogen 投与 後誘起される队膜上皮表面の微細構造の変化，乙とにその微絨毛や原形質突起に生ずる三次元像の変化，あ るいはこ机ら細胞表面の分泌動態などにつき検討した。

また次に，てのさい焱起される超微紐表面像の変化に関与する性ステロイドの役割を解析する目的で，ス テロイドホルモン投与下の去勢内膜上皮表面についてあわせ観察した.

なお走查型電顕を用いたこの方面の研究に関しては，現在のとてろ，ラット着床前期内膜を観察した Nilsson の報告 $(1972)^{10)}$ ，遅延着床ラット，マウスの内膜を検討した Psychoyos ら (1971) ${ }^{11)}$ ，Bergström 


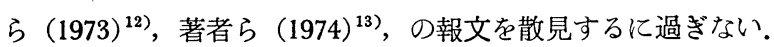

\section{I 実験材料および方法}

\section{1. 実験材料 (Fig. 1.)}

\section{A. 遅延着床ラットを用いた estradiol 投与実験}

体重 150 200gm の Wistar 系処女ラットを用い, 発情期に雄と同居させ，翌朝腟脂亳中の精子が確認 された日を妊娠第 1 日 $\left(\mathrm{L}_{0}\right)$ とした. そして Fig. 1. のごとく $\mathrm{L}_{2}$ 午前中に両側卵巣剔除を行ない以後, progesterone を1日 $4 \mathrm{mg}$ 連日皮下投与し， $\mathrm{L}_{7}$ に hexobarbital 麻酔下で試験開腹して，明らかな着床部 膨隆 (node formation) のないととを確かめ遅延着床ラットとした．との $\mathrm{L}_{9}$ 相当日に estradiol $0.1 \mu \mathrm{g}$ を 皮下投与し，経時的（ $8 ， 12 ， 16 ， 24$ 時間）にそれぞれ 3 匹の動物を hexobarbital 麻酔下で開腹し，子宮 を剔除した。

\section{B．卵巣剔除ラットを用いた性ステロイド投与実験}

正常周期ラットの卵巣を両側剔除し，少なくとも 2 週間以上無処置の動物を用い，前記の遅延着床実験に おいて投与した性ステロイドを同期間，同量を投与した．即ち，progesterone は $4 \mathrm{mg} /$ 日，7 日間連日投 与, estradiol は $0.1 \mu \mathrm{g}$ 投与し, さらに progesterone を $4 \mathrm{mg}$ /日 7 日間投与した後 estradiol $0.1 \mu \mathrm{g}$ を順 次投与し，その 12 時間後にA と同様に子宮を剔除した。

\section{2. 走査型電顕資料作製方法 (Fig. 2.)}

1) 洗浄, 固定

上記のごとく剔除した子宮はその周囲の脂肪，血管を除去し，生理的食塩水にて子宮外面及び子宮腔内 (flush out 法による) を洗浄し，直ちに 5\% glutaraldehyde（0.1M S $\phi$ rensen リン酸緩衝液 $\mathrm{pH} 7.4)$ で 30分間, 前固定を施し, 実体顕微鏡下で組織を長さ $3 \sim 4 \mathrm{~mm}$ に輪切し, さらに広間膜側を trimming し て同緩衝液中で30分間再洗浄を行なつた。 ての後 $1 \%$ Osmium 酸（同緩衝液にて稀釈）で 4 時間30分の後 固定を実施した。

2 ) 脱水, 乾燥

$70 \%$ ethanol からの上昇系列により脱水を行ない，徳永氏 ${ }^{14)}$ そる有機溶媒置換後自然乾燥法あるい は, 酢酸 isoamyl に置換の後, 液体 $\mathrm{CO}_{2}$ を用いて HCP-1 による臨界点乾燥を行ない, デシケーター内

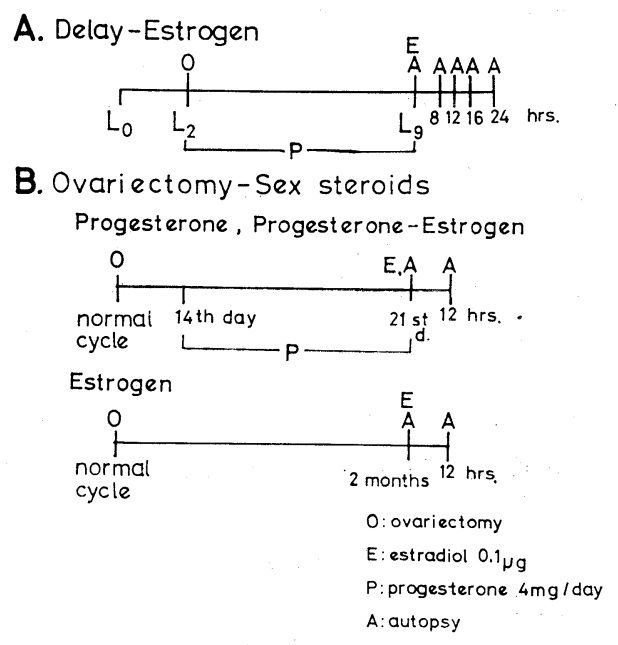

Fig. 1. Outline of Experimental Procedure
1) Hysterectomy

2) Clean up (removal of fat and blood): $0.9 \% \mathrm{NaCl}$ sol. by flush out method

3) Ist Fixation; $5 \%$ glutaraldehyde( $0.1 \mathrm{M}$ Sörensen phosphate butfer $\mathrm{pH} 7.4) \quad 1 / 2 \mathrm{hr}$

4) Trimming ; Chips of $3 \sim 4 \mathrm{~mm}$ length under the stereo microscope

5) Clean up $: 0.1 \mathrm{M}$ Sörensen phosphate buffer $\mathrm{pH} 7.4 \quad 1 / 2 \mathrm{hr}$ 6) 2nd Fixation: $1 \% 0 \mathrm{OSO} 4 \quad 4 \frac{1}{2} \mathrm{hrs}$

7) Dehydration: ethanol gradient

8) Drying iso-amyl-acetate: ethanol $=5: 1$ (Tokunaga's method) or Critical Point Drying with HCP-1 (Tanaka's method)

9) Keeping : desiccator $\left(\mathrm{CaCl}_{2}\right)$ 10) Coating $\quad$ Ist cat bon
2nd gold 11) Observation: JEOL JSM-U3 or HSM-2 (2OKV)

Fig. 2. Preparation of the specimen for SEM 
で保存した。

3 ) 蒸着, 観察

carbon一金または chrome一白金・paladium の二重蒸着を施して，JEOL JSM-U 3 または HSM-2（加 速電圧 $10 \mathrm{KV}, 20 \mathrm{KV})$ を用い鏡検した。

\section{II 実 験 成 績}

\section{A. estradiol 投与後誘起される遅延着床内膜の経時的な変化}

i ) 遅延着床時の内膜上皮表面の微細構造 (Fig. 3a, 3b)

遅延着床時の内膜上皮表面の微細構造は，既報（1974） ${ }^{13)}$ したごとく，その上皮表面は細胞境界が比較的 明瞭で，その輪郭は少し丸味をもち，細胞表面はやや陷凹もしくは裮曲しており， 1 細胞につき 2 亿個の 直径 $1 \sim 3 \mu$ 大の細胞質突起が分布している. そしててのような所見は透過型電顕像においても同様に豊 富な微絨毛，巨大な細胞質突起として把握可能である (Fig. 3b).

この外, 多数の触手状構造の集合した突出物すなわち Psychoyos (1971) ${ }^{11)}$ の指摘する “sea-anemone-like formations”が観察された.

微絨毛は一般に棍棒状を呈し，比較的均等かつ密に分布しており，また比較的稀ではあるが微絨毛の先端 部に一致して直径 $0.2 \sim 0.3 \mu$ の小型の apocrine 様突起を認めることもある.

a

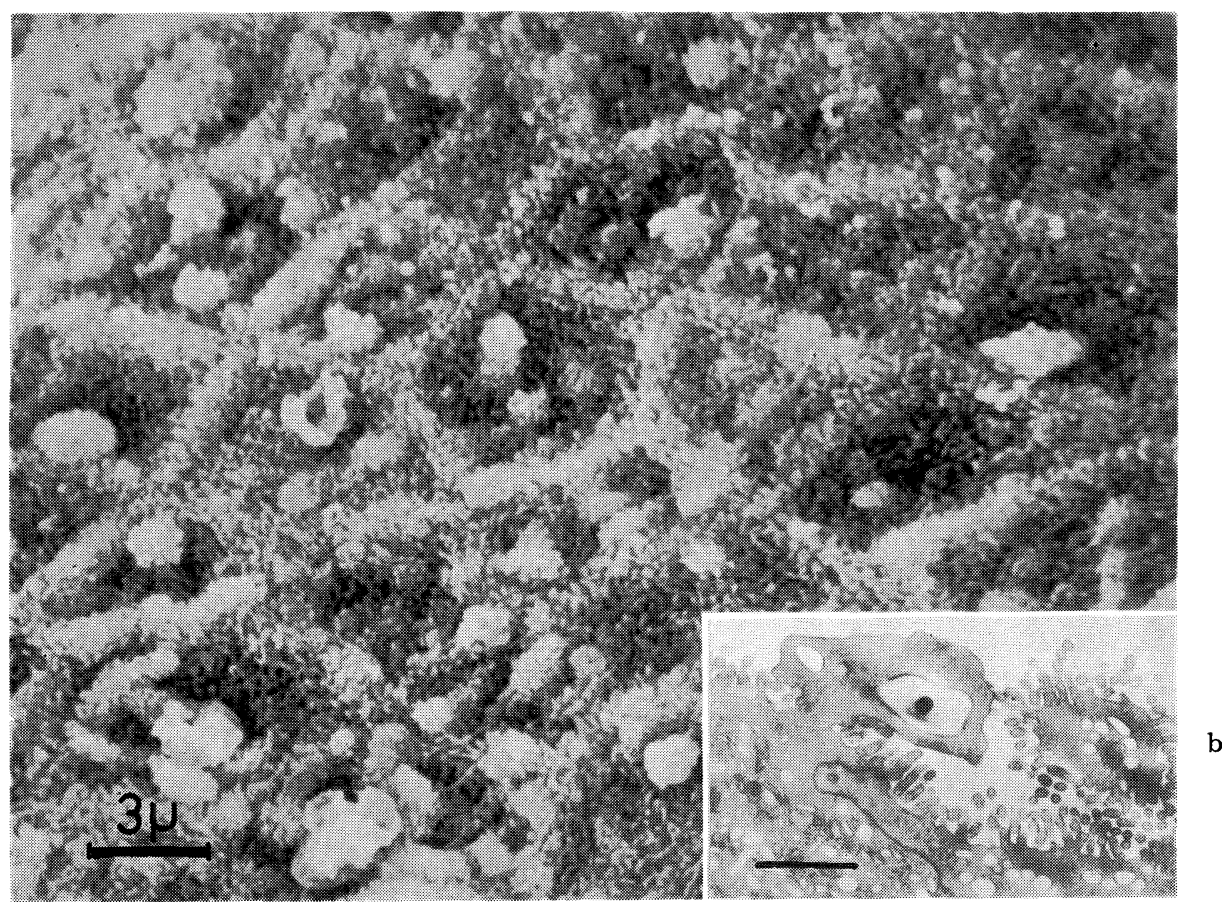

Fig. 3a. Luminal epithelial surface of rat uterus in delayed implantation (with critical point drying).

Arrangement of microvilli is dense. Many large cellular protrusions or "sea-anemone-like formations among the microvilli are seen. $\times 4460$.

Fig. 3b. Profile of luminal epithelium of rat uterus in delayed implantation. A large cytoplasmic protrusion, densely arranged microvilli and many apical vesicles are shown. $\times 12200$. 
ii) estradiol 投与後 8 時間目の上皮表面の微細構造 (Fig. 4.)

estradiol $0.1 \mu \mathrm{g}$ 投与後 8 時間目では，細胞境界は陥凹して不明瞭となり，その輪郭は不鮮明ながら長棈 円形を呈している。またその表面構造には著変がみられる。すなわち, 表面は 0.4 から $12 \mu$ 大の大小さま ざまの多数の半球状ないしは球状突出物によつて被われており，てれらのあるものは明らかに茎をもつて内 膜表面から突出している。またてのような apocrine 様に膨隆する細胞表面には短小な微䋘毛がきわめて疎 に附着しているものもある.

微緁毛は一般にやや短小化し，その太さは必ずしも一様でない．また，内膜表面全般に直徍 $0.2 \sim 0.3 \mu$ 大の小球状の構造が微緁毛の先端部にほぼ一致して多数観察された。

iii) estradiol 投与後12時間目の上皮表面の微細構造（Fig. 5.)

estradiol 投与12時間目では上皮表面はまだ細胞質が膨隆しているため粗造であるが，一部ではやや平坦 化している。また細胞境界は一般て細胞質の膨隆のため相対的に陥凹しているところが多く, 谷間のように みられるが，一部は細胞質の袥曲により，境界が不明瞭となつている。他方 8 時間目にみられた大型の球状 突出物は減少して，直径 $0.5 \sim 2 \mu$ 大のさまざまの細胞質突起が 1 細胞あたり 4 個分布している. てれらの 突起は膨満しているもの，あるいは裮曲が強く萎縮したかにみられるものが多く，極稀れであるが，その細 胞質突起の上に䈃状の構造物が付着してうらられることがある。

また微絨毛は全般的に短く不整で，その形状は先端部が風船状に膨隆したもの，あるいは円錐状に尖がつ ているものなどが混在しており，その配列は著しく不規則化している。

iv) estrodiol 投与後16時間目つ上皮表面の微細構造 (Fig. 6.)

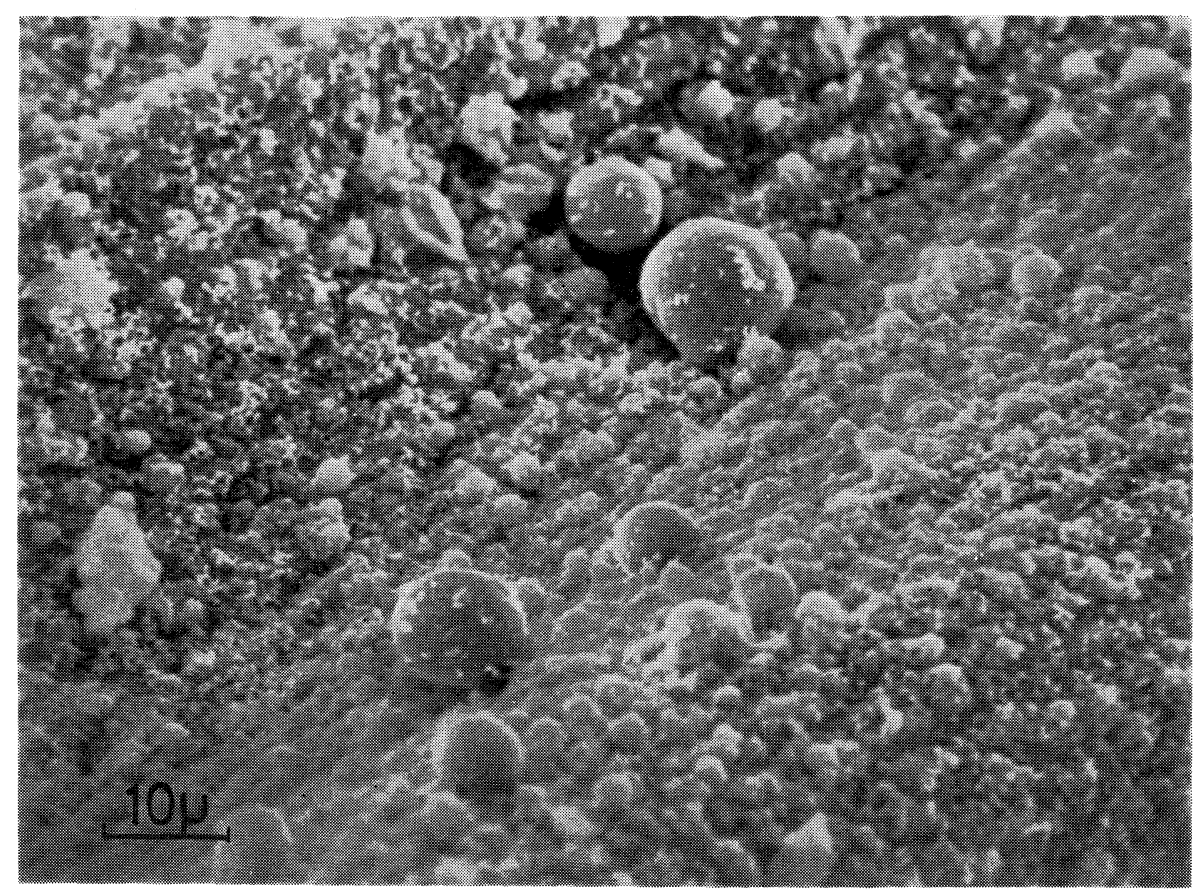

Fig. 4. Luminal surface of rat uterus, at 8 hour after the injection of estradiol $0.1 \mu \mathrm{g}$ (with Tokunaga's method).

Some large globular protrusions are originated from the endometrial surface with stalk. On the protrusions, a few short microvilli are attached. A large number of similar protrusions are observed. $\times 1500$. 
estradiol 投与16時間目になると, 内膜表面は明らかに平坦化し, 細胞境界は突出して明膫となる。また この時期の特徵的な所見として，小型の apocrine 様構造はなおかなり多数認められるが，8時間目の内膜 表面にみられた大型の apocrine 様球状突出物は明らかに減少しており, このような所見に加えて, 膨隆し た細胞膜の破綻を思わしめる, その中央部の陥凹したあるいは小孔を有する細胞質突起が多数みられた。

他方, 微絨毛は繁茂しているが, その形状は対象の遅延着床内膜と比較して, 太く海草状を是しており, またその多くは屈曲していた。

v) estradiol投与後24時間目の上皮表面の微細構造 (Fig. 7a, 7b)

この時期の上皮表面は，その細胞境界は隆起して明瞭となり，細胞質の中央部か浅い宿凹を示し，細胞表 面は全般的に鱗片状として観察される。 また細胞質突起は明らかに小型化しており，その数も 1 細胞につき $1 \sim 2$ 個と減少していた.

他方, 微絨毛は依然繁茂しているが，その長径は明らかにより短小化しており，また屈曲している。また このさいの透過型電顕所見では, 細胞表面の微絨毛の短縮やその配列の不規則化ぶみられ, apical vesicles

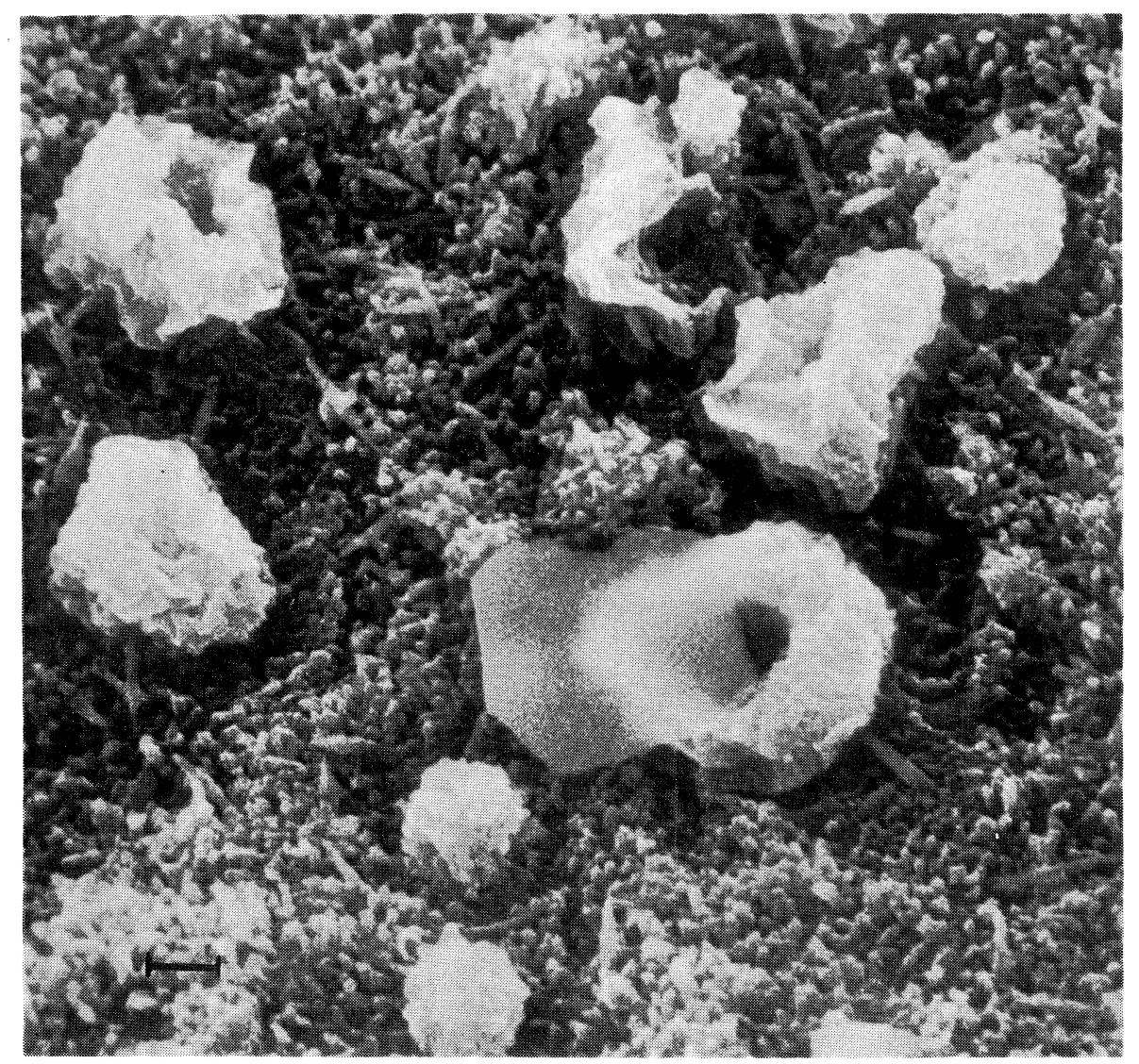

Fig. 5. Luminal surface of rat uterus, at 12 hour after the injection of estradiol $0.1 \mu \mathrm{g}$. (with C.P.D.).

Many cellular protrusions are wrinkled. Occasionally thin foil like structure is attached to the protrusion. Microvilli are short, irregular. Some of them show baloon-like bulgings. $\times 9800$. 
は著明に減少, Golgi 装置も縮少していた (Fig. 7b).

\section{B. 性ステロイド投与による卵巣剔除ラット内膜の表面超微細構造の変化}

i ) 卵巣剔除無処置群の内膜上皮表面 (Fig. 8.)

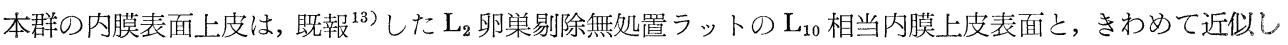

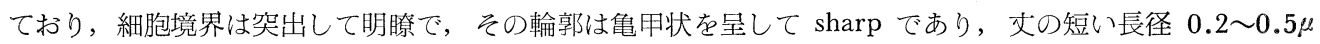
大の微絨毛が粗に分布しているのが観察された。他方, 巨大な細胞質突起はほとんぞ認められず, 小型 apocrine 様の突出物が極少数散見されるのみであつた。

ii ) progesterone 投与（4 mg/日 7 日間）群の内膜上皮表面 (Fig. 9，10a，10b，10c，11)

本群の内膜表面上皮は，細胞境界は少しく突出して明瞭で，その輪郭は多角形を呈し，その表面は少しく 陥凹やや裮曲しており，形の整つた微䋘毛が繁茂して，直径 $1 \sim 3 \mu$ の細胞質突起が各細胞にほほ 1 個づ つ分布していた (Fig. 9.)。乙れら細胞質突起の形態はさまざまで, 微絨毛がクレーター状に隆起した細胞質 の表面を被うもの (Fig. 10a), 微縅毛を欠く巨人な細胞質突起の中央部が陥山して, その陷凹部内にさらに 隆起物のみられるもの (Fig. 10b), さらに突起全体が入道雲のように物質の放出を思わせるもの (Fig. 10c)

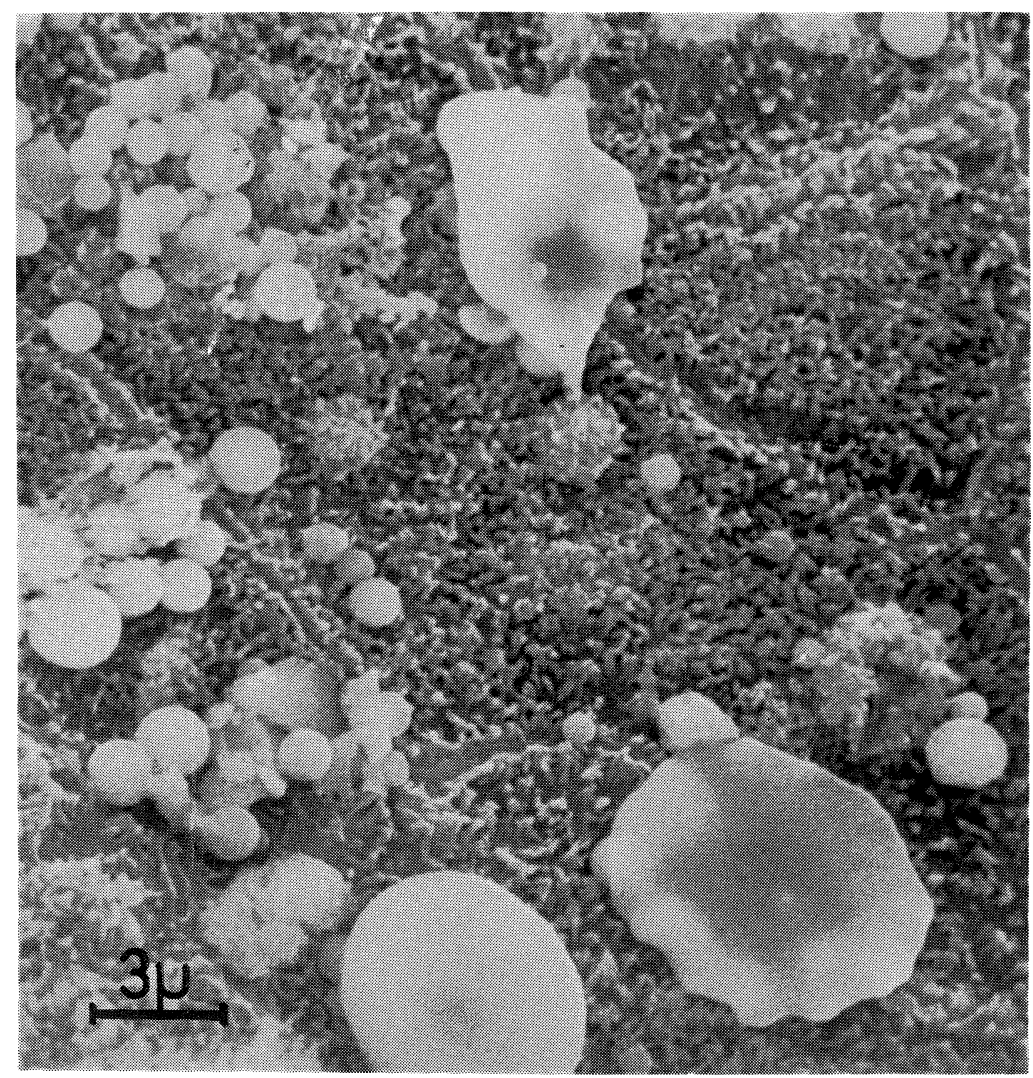

Fig. 6. Luminal surface of rat uterus, at 16 hour after the injection of estradiol $0.1 \mu \mathrm{g}$. (with Tokunaga's method).

A cellular protrusion concaved in the center and many small macroapocrine-like structures are seen. Microvilli are densely arranged but shorter and more bended than those before the treatment of estradiol. $\times 4500$ 
$\mathrm{b}$

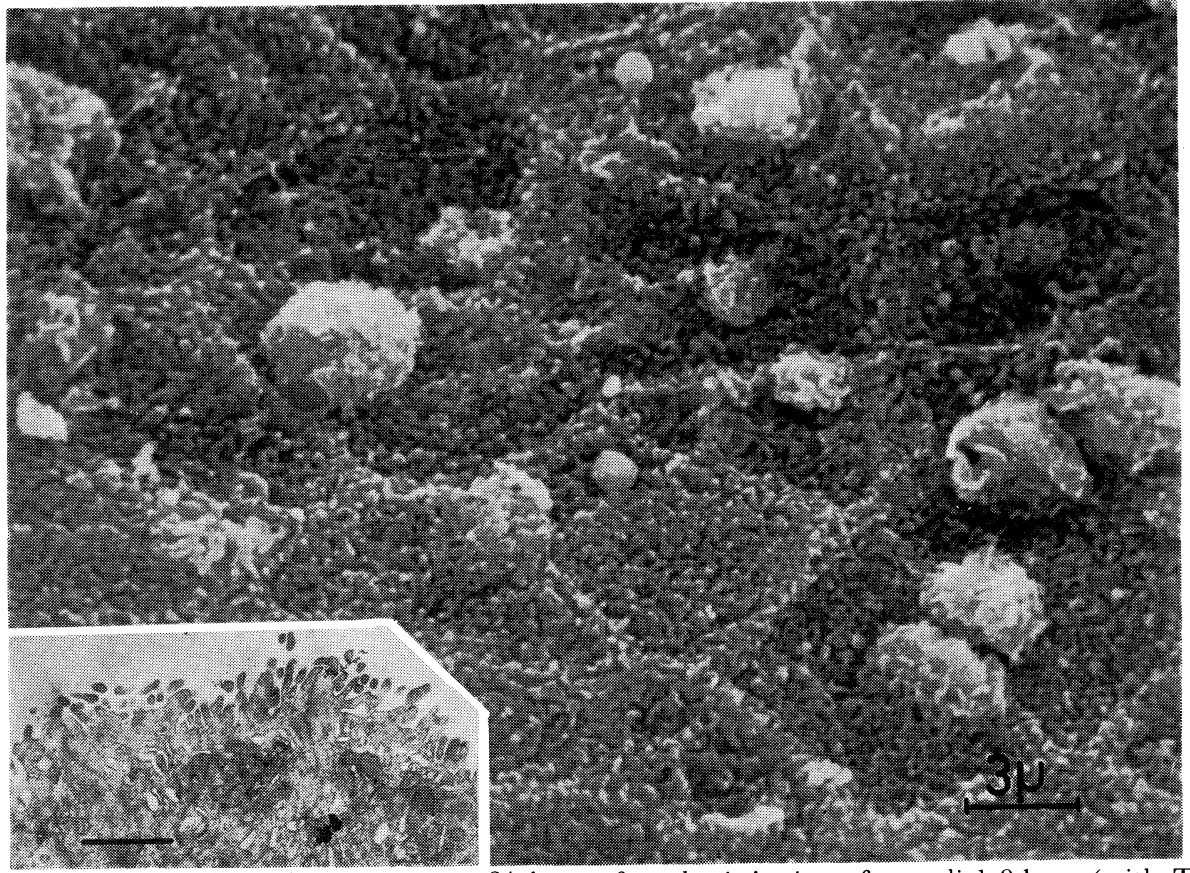

Fig. 7a. Luminal surface of rat uterus, at 24 hour after the injection of estradiol $0.1 \mu \mathrm{g}$. (with Tokunaga's method). Most of cellular protrusions are wrinkled. Cellular surface is generally flattened. Microvilli are shortening and are more bended. $\times 4500$.

Fig. 7b. Profile of luminal epithelium of rat uterus, at 24 hour after the injection of estradiol $0.1 \mu \mathrm{g}$. Microvilli are shortened and sparsely arranged. Apical vesicles are mostly disappeared. $\times 10500$

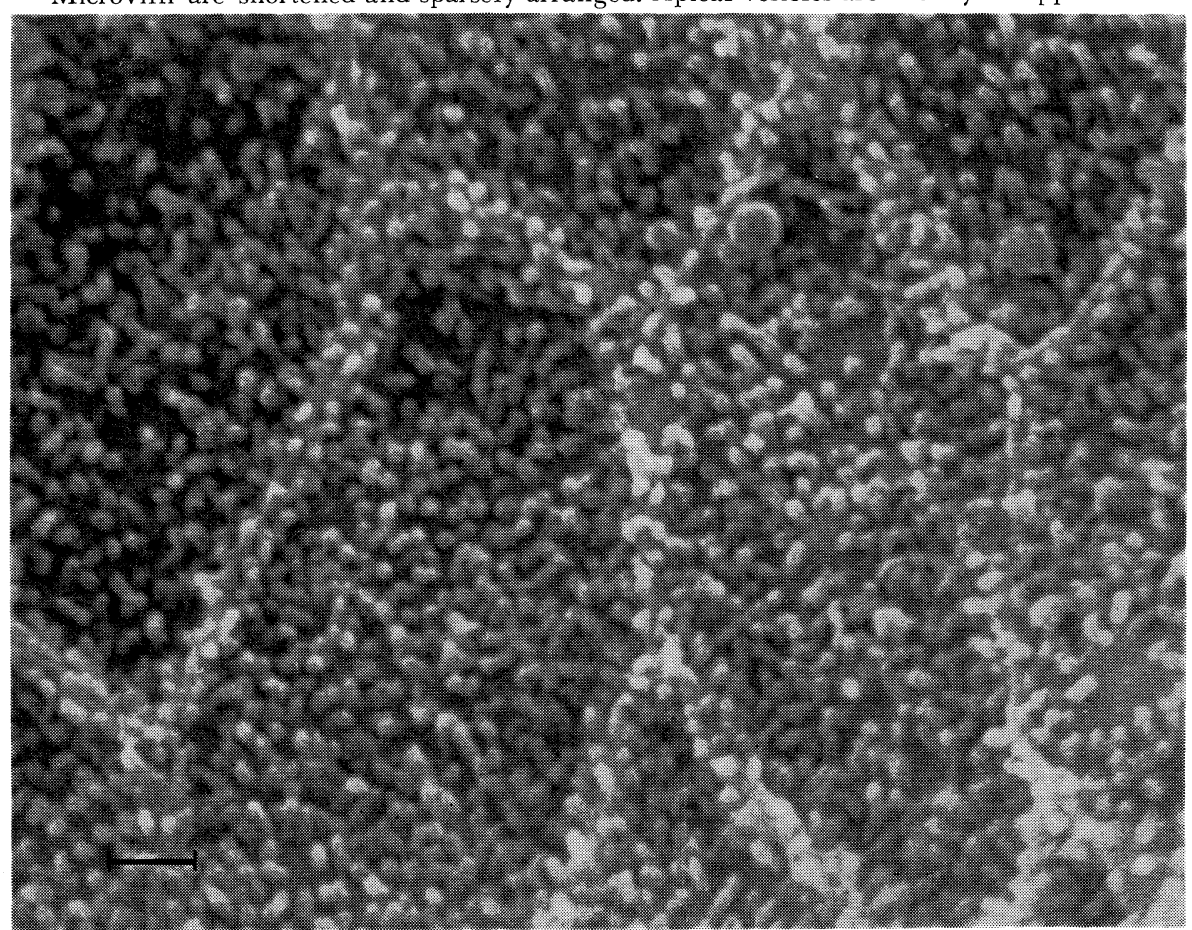

Fig. 8. Luminal surface of rat uterus castrated for 2 weeks (with G.P.D*). Gellular border is markedly clear and cellular surface is generally concaved. Short microvilli distribute very sparsely. Occasionaly small globular bulging at the top of the microvillium is observed. $\times 10005$ 第 50 巻 第 4 号 


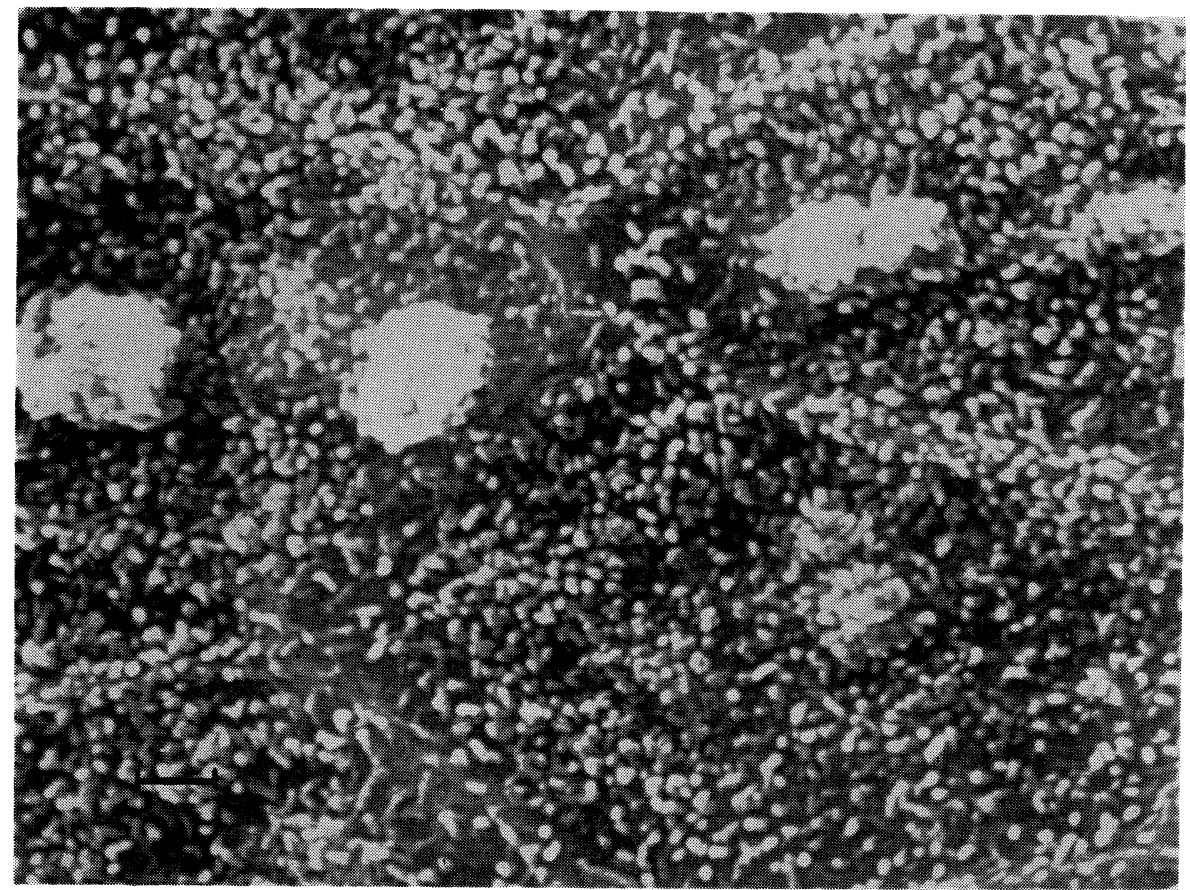

Fig. 9. Luminal surface of a rat treated with daily injection of progesterone $4 \mathrm{mg}$ for 7 days. (with C.P.D.). Arrangement of microvilli is dense, a large cellular protrusion and a few "sea-anemone-like formations" are seen. $\times 9000$.

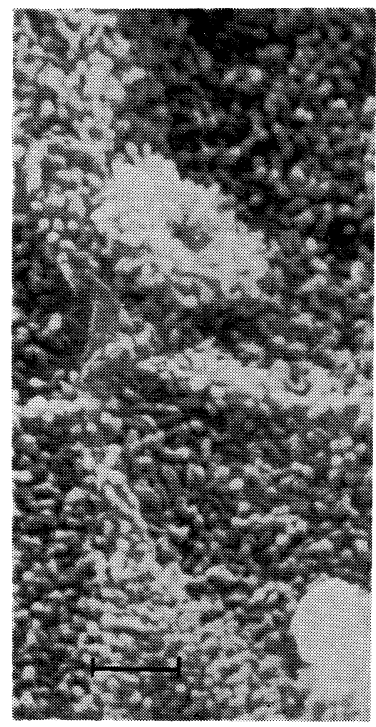

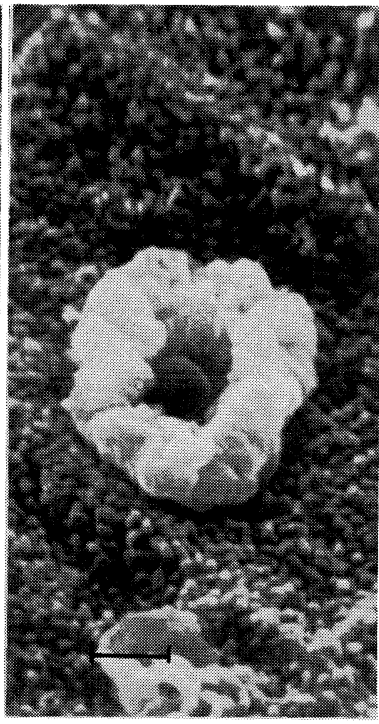

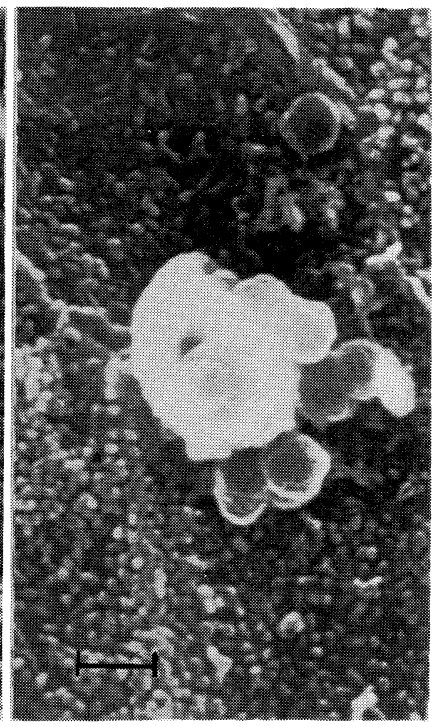

Fig. 10. Various forms of cellular protrusions. Treated with daily injection of Progesterone $4 \mathrm{mg}$ for 7 days. (with G.P.D.).

a. A crater-like protrusion with many microvilli on its surface. $\times 12000$.

b. Note the globular structure in the center of the protrusion. $\times 12000$.

c. Protrusion with a structure like a gigantic columns of clouds, releasing from it. $\times 11300$. 
などが観察できた。

すなわち，乙礼らの所見は細胞質乫起が黒住のいら放出機序II 型を営む可能性のあるてとを示唆している。 てのほか，ほとんどの細胞表面に微䋐毛あるいは触手様構造の集合した乫出物が認められており，とくに この内巨大なものは, 腺開口部樣陌四部近傍で多く認められた。すなわち本構造はPsychoyos (1971) ${ }^{11)} の$ いう，いわゆる “sea-anemone-like formations”に相当するものと思われる。また少数ではあるが，微䄉毛 の先端部に一致して球状の構造か認められる (Fig. 11,).

iii) estradiol 投与群の内膜上皮表面 (Fig. 12a, 12b)

estradiol 投与 $(0.1 \mu \mathrm{g}) 12$ 時間目における上皮表面の構造は, 卵巣剔除時内膜とその概観はかなり近似し ているが，乙のさいの微絨毛は明らかに伸長しており，またその先端部に一致して $0.4 \sim 1.2 \mu$ 大の球状の 構造物が付着, 分布しており, その小さいものは微絨毛之明らか汇連続性をもつているてとが観察できた。 このような特異な形態像は，われわれの行なつた estradiol $2 \mu \mathrm{g}$ 子宮腔内注入後，24時間目の卵巣剔除内膜 表面上皮にみられた微絠毛の先端部膨潤あるいは polyp 様変形と符合する所見（Fig. 12b）であり，本所見 は明らかに黒住のいう分泌様式第而型 (microapocrine) の走査型電䫓所見を示すものと思われる.

iv) progesterone-estradiol 順次投与群の内膜上皮表面 (Fig. 13.)

progesterone t $4 \mathrm{mg} /$ 日， 7 日間投与した後， estradiol $0.1 \mu \mathrm{g}$ を投与し，その12時間目の内膜を観察し た. このさいの内膜は全般的に褶曲し，細胞境界は少しく突出するものの概して不明瞭である．またその輸 郭は丸味を带び，細胞質突起の数は 1 練胞あたり $3 \sim 4$ 個と progesterone 単独投与群と比較して明らかれ 増加しており，またその大きさも直径 $0.4 \sim 2.4 \mu$ 大とさまざまであるが, estradiol 投与後の遅延着床内膜

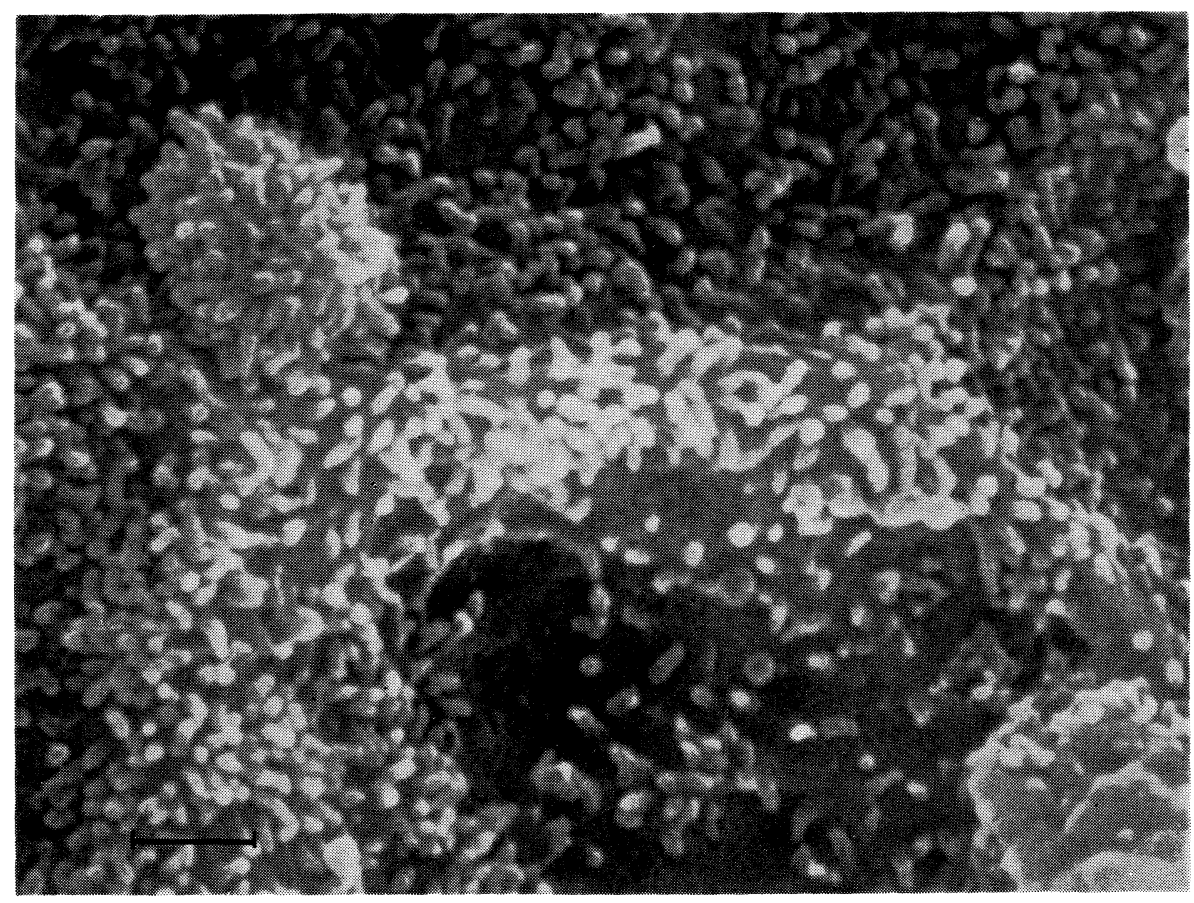

Fig. 11. Luminal surface of a rat treated with daily injection of progesterone $4 \mathrm{mg}$ for 7 days. (with C.P.D.).

A large "sea-anemone-like formation" near-by a concave suggested the glandular orfice and small globular bulgings at the top of microvilli are seen. $\times 15000$. 
において観察された細胞質突起と同一性格の，つまり macroapocrine 様分泌放出後の細胞質突起とも思わ れるものを数多く認めた。

またてのさいの微絨毛は短小化し，その先端部は太く，その多くは屈曲化しており，さらに微絨毛先端部 の microapocrine 様突起も progesterone 単独投与群汇比し増加していた.

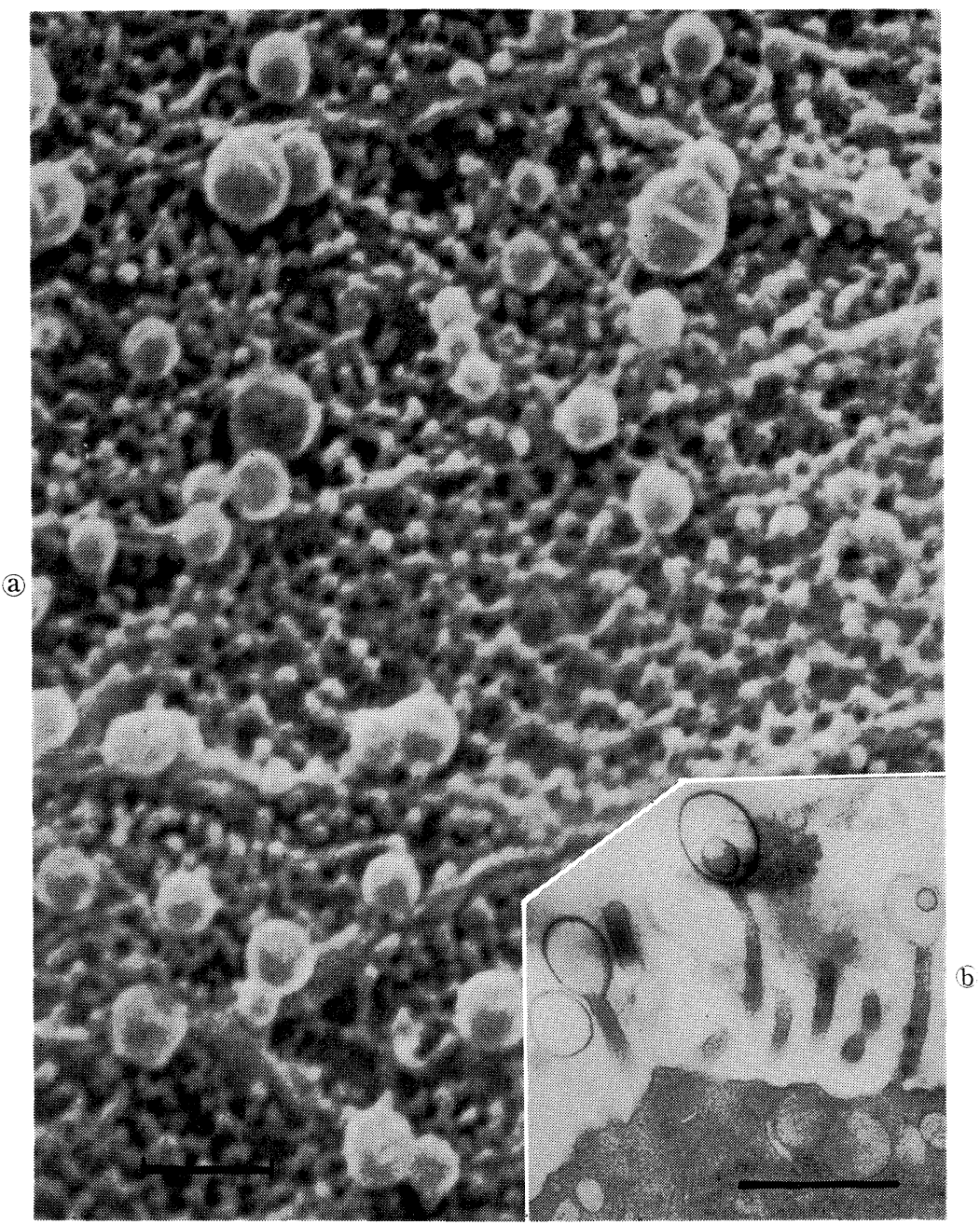

Fig. 12a. Luminal surface at 12 hour after the injection of estradiol $0.1 \mu$. (with C.P.D.).

Globular structures are attached to the top of microvilli and small one is continued with the underlying microvillium.

Generally, the microvilli are slightly longer than those of castrated rats, but they are bulged and clubbed like at the top of them. $\times 15000$.

Fig. 12b. Profile of the luminal epithelium in the castrated rat, at 24 hour after the intraluminal injection of estradiol $2 \mu \mathrm{g}$.

Note the marked bulging at the top of the microvillium. $\times 18300$. 


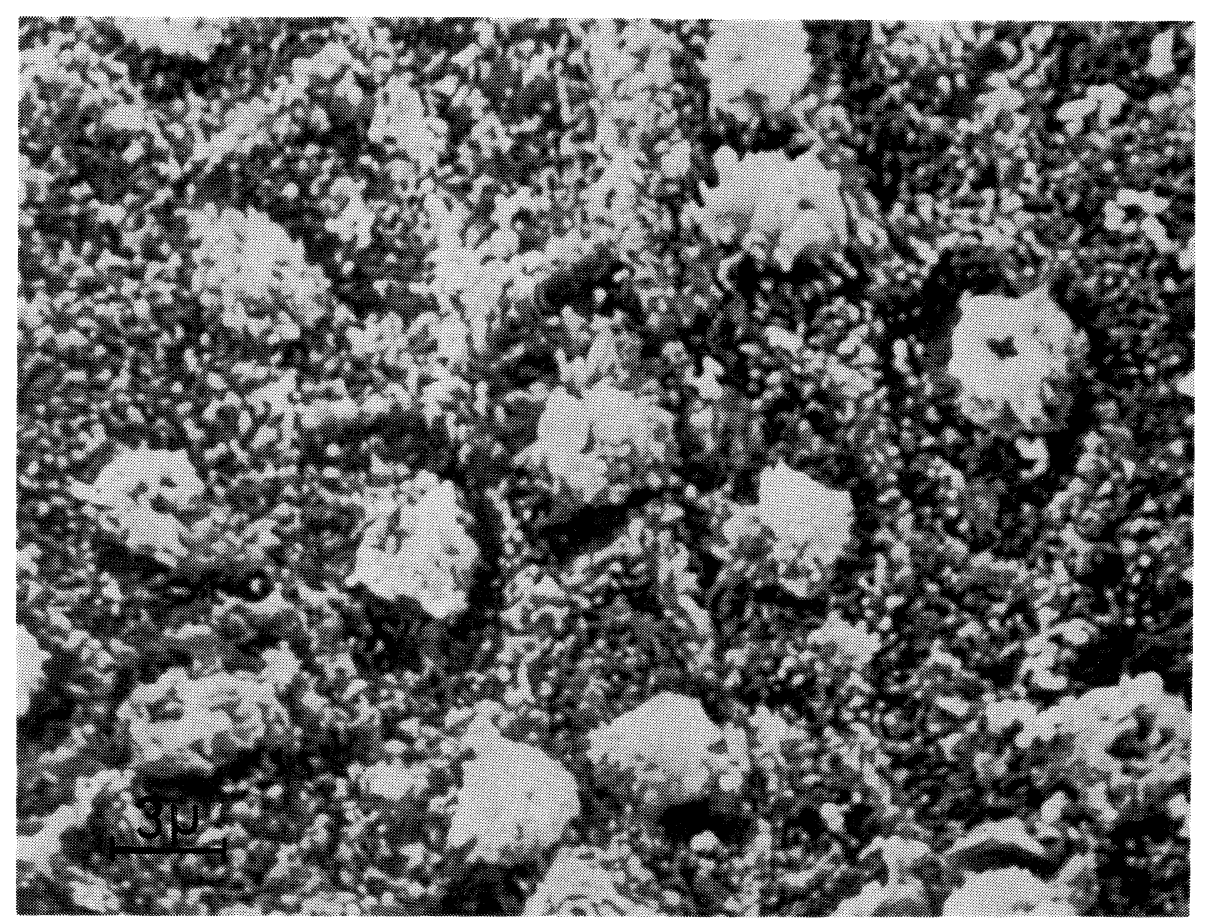

Fig. 13. Luminal surface, at 12 hour after the sequential administration of progesterone and estradiol (with G.P.D.).

Similar picture to those observed at 12 hour after the injection of estradiol in delayed implantation are seen. $\times 4500$.
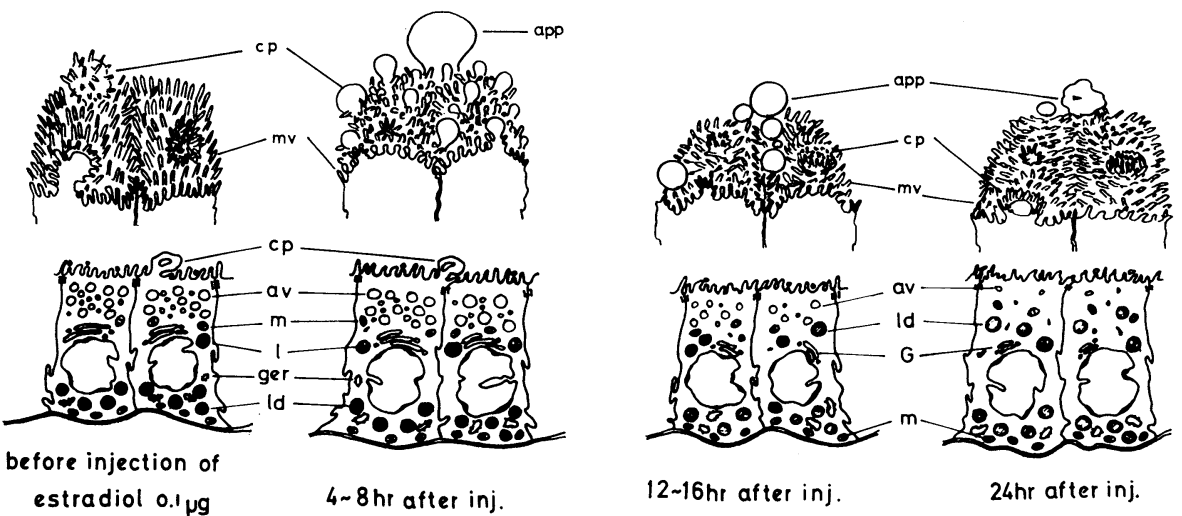
mv : microvilli
G : Golgi complex
1 : lysosome
cp : cytoplasmic protrusion
$\mathrm{m}$ : mitochondrion
ger : granular endoplasmic reticulum
app : apocrine like projection

av : apical vesicle

ld : lipid droplet

Fig. 14. Estrogenic Transformation of Luminal Epitheliumin Delayed Implantation.

- SEM and TEM findings - 


\section{III 考按}

組織の表面構造はそれ自体固有の機能を何等かの形で表現しているものである.

そこで著者らは胚着床の機序を形態学的に究明する手段の一つとして，以上のでとき実験を行なつた。

まず，胚着床阻止環境にある遅延着床時内膜の表面上皮超微細構造に関して，Enders (1967) ${ }^{2)}$ は透過型 電顕を用い，乙のさいの内膜表面上皮の微縅毛は粗に分布し，また短小であるとしているが，乙の見解は著 者らの走查型電顕を用い繁茂せる微絨毛の存在を確かめ得た今回の検索結果と明らかに相反するものである。

また Nilsson $(1972)^{10)}$ はこのさいの微絨毛に microdroplet の付着をみ，こうした小構造は恐らくは微 䄉毛の分泌機能と相関を持つであろうと推定しているが，著者らの今回の成績では microdroplet の付着は 必ずしも明確でなく，乙の点標本作製技術の問題をも含め，さらに詳細な検討を要するものと思われる.

しかしながら, Nilsson (1972) ${ }^{10)}$ やPsychoyos ら (1971) ${ }^{11)}$ の指摘する細胞質突起やいわゆる“sea-anemone-like formations” に関しては, 本研究においても豊富に認めるてとができた. 前者は透過型電顕所見 上のいわゆる “fungus-like protrusion” に明らかに該当するものと考えられるが，後者の透過型電顕像の 詳細に関しては現在のところ明確でなく，Psychoyos ら (1971) ${ }^{11)}$ は単に protrusion に相当するとしてお り，なお今後の検討が必要である.

ところでこのような protrusion や “sea-anemone-like formations”についてであるが, Psychoyos (19 71) ${ }^{11)}$, Nilsson (1972) ${ }^{10)}$, Berrgström ら (1973) ${ }^{12)}$ は肧は遅正着床下においても protrusion と密接し, 加 えて protrusion は表面上皮から離出, その胞体内に含まれる蛋白性物質を放出するという観点から, protrusion は微絨毛とともに, 胚への重要な蛋白性物質, アミノ酸補供路と考えている. 事実, 谷 $(1974)^{15)}$ も妊娠ラットを $\mathrm{L}_{2}$ に卵巣剔除，以後 progesterone を投与せずそのまま放置すると，胚回収率は $\mathrm{L}_{8}$ 以降 著しく低下するてとを認めており，またてのさいの上皮表面構造について検討した著者らの研究結果（19 $74)^{13)}$ によると後述する卵巣剔除時内膜と同様に, protrusion を欠いているのでての可能性はきわめて強 いと推定される.

また本研究においては微䄉毛に明確な microdroplet こそ認め得なかつたものの, 前述した通り, 微絨毛 に少数の microapocrine 様突起の形成や分泌物の流出を思わしめる不規則な陥凹を持つ protrusion を認め ており, 本所見は上皮胞体内に豊富にみられる限界膜を持つ apical vesicles の存在, あるいは発達した Golgi 装置の所見などとともに，微絨毛や protrusion の分泌能を明示するものとも考えられる.

次に著者らは遅延着床ラットに着床誘導量の estradiol を投与, 乙のさい生じる内膜の超微細表面像の変 化を経時的に追究してみた。

この結果，estradiol 投与 8 時間後に内膜被覆上皮表面の一般的な膨隆，微絾毛の短小，增巾，または不 整化，さらに多数の apocrine 様突起の形成をみ，16時間後では微絨毛が一層短小，屈曲し，扁平化するほ か, 恐らくは胞体内容の流出に起因すると考えてよい細胞質表面の平坦化, あるいは中央部が陥凹し, 表面 の著しく褶曲した細胞質突起が多数観察された.

すなわち，乙れらの所見は遅延着床内膜表面上皮は estradiol の投与を trigger として開口分泌 exocytosis, eruptocrine あるいは apocrine 分泌の著しい方進をみ, その後分泌の低下をきたすとともに, 胞体内 容の流出に基づく上皮の扁平化を招来することを示唆するものと解釈することも可能である.

またてれに関連して，乙のさいの従来の組織化学的検索結果についてみれば， estrogen 投与後表面上皮 の核下脂肪の減少 (Takano, 1972 ${ }^{16)}$, Elftman 1958 ${ }^{17)}$ ) や上皮遊離面に局在する alkaline-phosphatase 活 性の一過性の増強とそれに引き続く低下(Takano, 1972 ${ }^{16)}$ ) あるいは上皮胞体の ${ }^{3} \mathrm{H}$-cystidine, ${ }^{3} \mathrm{H}$-uridine のとりてみ増加 (Prasad ら 1968 ${ }^{18)}$, Takekida, 1971 $\left.{ }^{19}\right)$ ) などの変化が観察されており, ての中でも alkalinephosphatase 活性の上昇や ${ }^{3} \mathrm{H}$-uridine のとりとみの増加は estradiol によつて誘起される細胞膜透過性の 変化あるいは胞体内の蛋白合成の高まりを端的に示唆するものと思われる。

またわれわれの行なつた，乙のさいの透過型電子顕微鏡所見 $(1973)^{20)}$ を, 今回の走查型電子顕微鏡所見 
と対比すると Fig. 14 のようである.

すなわち estradiol 投与 4 時間後に表面上皮の polysome は明瞭となり粗面小胞体の内腔拡大像がみら れ，12時間後では apical vesicles の減少，Golgi 装置の縮少，lysosome 系顆粒の増加をみ，24時間後には これらの所見に加えて微絊毛の短縮やその配列不整化が出現し, 前述の走查型電顕所見とよく符号する所見 が多く認められた。

そしてとくに，乙のさいの表面上皮の attachment reaction つまり同部にみられる apical vesicles の減 少, lysosome 系顆粒の増加, 微縅毛の短縮不整化加開口分泌もしくは a pocrine 様分泌の動態と恐らくは 密接な関連性をもつことは，Douglas ら $(1971)^{20)}$ の提唱する exocytosis-endocytosis cycle の問題にも関 連して，一応注目すべき所見と考えられる。

また Pottsら $(1967)^{21)}$ は透過型電顕を用いて，てのさいの apical vesicles の減少が上皮表面からの protrusion の遊離もしくはその崩壊に起因すると解釈しているが，てうした考え方も protrusion の開口分 泌を思わせる所見を認め得た今回のわれわれの成績を支持するものと考えられる.

ところで, 性ステロイドの投与により誘起される卵巣剔除時内膜の超微細表面像の変化に関しては, 前述 したでとく, 卵巣剔除時の内膜表面構造は平坦で, 短い微絨毛が粗に分布, 極少数の小型 apocrine 様突起 の散在を認め得たに過ぎなかつたが progesterone 投与下では，その様相は一変し，繁茂する微緁毛や少数 の小型 apocrine 様突起のほかに，てのさいの特異的な構造として cellular protrusion あるいは“seaanemone-like formation”の出現をみ，一見して遅延着床時のそれときわめて近似する所見が得られた.

またさらに, progesterone 投与下にみられる protrusion の形態はさまざまで，その間にいくつかの移行 型とみてよい多彩な構造を認め得るととについては前記した通りである.

てれに対して estradiol 投与下では, その特徴的な所見として微絨毛に多数の microapocrine 様突起の形 成が認められたが，本所見は同じ条件下で透過型電顕による観察を行なつた Liunkvist $(1972)^{22)}$ の報告では 明確な記載がなされていない.

さらに progesterone と estradiol の順次投与で microapocrine 様突起の形成のほか, macroapocrine 様 分泌後の protrusion を思わしめる構造を多数観察できた.

すなわち，以上の知見から，少なくとも著者らの行なつた実験条件下では protrusion の形成は主として progesterone 依存性, 他方 microapocrine 様突起の形成はおもに estradiol に依存していることが明らか であり，また progesterone-estradiol 順次投与下の超微細表面像は estradiol 投与後の遅延着床内膜ときわ めて類似していることも判明した.

ととろで腺細胞の分泌物放出過程に関しては，古くRanvier $(1887)^{23)}$ とより全分泌 holocrine と部分分 泌 merocrine に二大別されており, その後, Schiefferdecker (1992) ${ }^{24}$ は後者をさらに離出分泌 apocrine と 漏出分泌 eccrine とに細別している.

また比較的最近になつて黒住 $1965^{25)}$ は透過型電顕所見から, 分泌物の放出形態を i) 全分泌 holocrine mechanism, ii) 大離出分泌 macroapocrine mechanism, iii) 小離出分泌 microapocrine mechanism, iv) 開口分泌 eruptocrine, reverse pinocytosis，v) 透出分泌 transmembranous permeatation の 5 型に分類 し，臟器特殊性はあるが，一般に正常状態では多くの場合 iv)，v）の様式をとるととが多く，てれに対し て ii)，iii）の分泌型式は強い刺激下でのいわば強制放出様式とみなすととが可能であるとし，また Smith $(1971)^{26)}$ や菅野 $\left.(1972)^{27}\right)$ らはいわゆる Ga 依存性開口分泌は内分泌性，外分泌性腺細胞のみならず，コ リン作働性, アドレナリン作働性 neuron や多型核白血球, 塩基性白血球, 肥満細胞, 血小板などの遊離細 胞においても認められることを明らかとした.

しかしながら，てれらの分泌形態とくに macroapocrine, eruptocrine についての走查型電顕像に関する 知見はなお乏しく，また macroapocrine 分泌自体の実在に関しても黒住 $(1971)^{28)}$ が述べているように， 今後追求する余地が多々残されているというのが実状である.

したがつて，乙うした問題点はこてでは一応おくとしても， estrogen の投与によつて誘導される表面上 
皮の apocrine 様突起の形成は，膜透過性の変化に基づく，おそらくは一種の強制放出様式とみるととも可 能であり，てのような分泌物の放出は肧着床過程において恐らくは肧の活性化 (active blastocyst) に直接 役立つとともに，分泌物自体の胞体外流出に由来する表面上皮の扁平化を必然的に招来し，てのようにして 菲薄化した表面上皮は, 肧の内膜固定化に，あるいは肧性刺激伝達路として，より有効に機能することが考 えられる。

他方 estrogen の生物学的作用に関しては, 従来主としてその gene regulation に起因する細胞増殖作用 が注目されてきたが, progesterone priming 下の内膜上皮において, estrogen は一過性の分泌機能を誘起 したのち，ついで上皮の菲薄化さらに autodegeneration を招来するという事実は，Saunders ら $(1962)^{29)}$ の， 細胞変性も gene regulation の統御下にあるという見解を考慮するとき, trophoblastic invasion の機序 (Finn ら 1964) $)^{30)}$ と関連して, はなはだ興味ある知見であると思われる.

結 論

ラット着床過程における子宮内膜上皮表面の微細構造の変化とその内分泌調節の実態を究明する目的で, 遅延着床，卵巣剔除動物を用いて，走查型電子顕微鏡による観察を行ない，次のような結果を得た。

1 ) 遅延着床時内膜の上皮表面は数多くの巨大な細胞質突起を認め, 微䄉毛は比較的繁茂しており, 少数 ながら microapocrine 様突起の形成も認められた。

2 ）遅姃着床ラットに着床誘導量の estradiol を投与した結果，投与 8 時間目を中心に内膜上皮の分泌充 進を思わせる像が出現し, その後, 分泌現象の低下をきたすとともに, 上皮の扁平化や細胞質突起の菱縮, 微絨毛の短小屈曲化などの所見が観察された.

3 ）卵巣剔除ラット内膜表面の微絨毛は短小でその分布も粗であつたが，progesterone 投与時では比較的 繁茂する微絨毛と巨大な細胞質突起の形成か観察でき，一方 estradiol 投与群ではその12時間目に微緁毛の 先端部に多数の microapocrine 椂突起の形成が認められた。 またさらに progesterone-estradiol 順次投与 群においては同様の microapocrine 様突起が多数形成されるとともに, macroapocrine 様分泌後と思われ る細胞質突起が多数認められ, てれらの状態は, estradiol 投与後の遅延着床内膜ときわめて類似していた.

4 ）最後にてのような内膜上皮表面の微細構造の変化とその肧着床に関与する機能的意義についても論及 を加えた。

おわりに本研究の遂行にあたり, 御指導, 御校閲睗わりました東條伸平教授に心より感謝いたします.

\section{文献}

1) Blandau, R.J. : Biology of eggs and Implantation in "Sex and internal secretions" (Young, W.C. ; ed.), 3rd. (1961) Vol. 2, 797, Williams \& Wilkins, Boltimore, Maryland.

2) Enders, A.C. and S.J. Schlafke : Am. J. Anat., $120: 185$, (1967). $\quad 3)$ Mayer, G., O. Nilsson and Reinius : Z. Anat., $126: 43$ (1967). $\quad$ 4) Potts, M. : The ultrastructure of egg implantation. In advances in reproductive physiology (McLaren, A. ; ed.), Vol. 4, (1969), 241, Logos Press, London. Nilsson, O. : Ovo-Implantation. Human Gonadotropins and Prolactin, (1970), 52, S. Karger Basel München, New York.

6) Tachi, S., C. Tachi and H.R. Linder : J. Reprod. Fert., $21: 37$, (1970).

7）飯境理八：第23回日本産科婦人科学会総会宿題報告要旨, (1971).

8) 林 要, 李文遠, 松岡謙二, 武木田博祐 : 日内泌誌, $48: 533$, (1972). 99) 林 要, 李文遠, 松岡謙二 : 日 産婦誌, $25: 1208$, (1973). 10) Nilsson, O. : J. Ultrastructure Research, $40: 572$, (1972). 11) Psychoyos, A. and P. Mandon: J. Reprod. Fert., $26: 137$, (1971). 12) Bergström, S., and O. Nilssoh : J. Reprod. Fert., 32 : 531, (1973). 13) 林 要, 浜西正三, 李文遠 : 日産婦誌, 26(1), 69 ：(1974). 14) 徳永純一, 幡場良明：細胞, 3(13)：17, (1971). 15) 谷立夫 : 日産婦誌, 
26(4), in press, (1974).

16) Takano, S. : Kobe Journal of Medical Science ; $18: 179$, (1972). 17) Elftman, H. : Endocrinology, $62: 410$, (1958).

18) Prasa, M.R.N., G.M.S. Dass and S. Mohla : J. Reprod. Fert., $16: 97$, (1968).

19) Takekida, H. : Acta Obstetrica et Gynecologica Japonica, $18: 200$, (1971). 20) Douglas, W. W., J. Nagasawa and R. Schulz : Mem. Soc. Endocrinol., $19: 353$, (1971). 21) Potts, M. and A.C. Psychoyos : r. hebd. Séanc. Acad. Sci., Paris. $264: 370$, (1967). 22) Ljukvist, I. : Fert. Steril., $23: 847$, (1972).

23) Ranvier, L. : J. de Microgr., $11:$ 7, (1887). 24) Schiefferdecker, P. : Zoologica, $72: 1$, (1922). 黒住一昌 : J. Electron Microscopy, $14: 12$, (1965). 26$)$ Smith, A.D. : Phil. Trans. Ray, Soc. Lond. B., $261: 423$, (1971). 27) 菅野富夫 : 臨床生理, $2: 35$, (1972). 柴崎晋, 中尾真, 渡辺陽之輔, 山元寅男, 黒住一昌 : 医学のあゆみ, $79: 267,(1971)$. 28）菅野富夫, ders, J.W. JR., M.T. Gasseling and L.G. Saunders : Devl. Biol., 5 : 147, (1962). 29) SaunA. and J.R. Hinchliffe : J. Reprod. Fert., $8: 331$, (1964). 30) Finn, G. 